\title{
BAHAYA PASIEN PENDERITA DIABETES MELITUS TERPAPAR COVID-19 PADA MASA PANDEMI SEKARANG
}

\author{
Putri Shintia Joice Boluㄹ, Muhammad Ali Sodik ${ }^{2}$ \\ Instittut IImu Kesehatan Strada Indonesia \\ punk.putri13@gmail.com, alisodik2021@gmail.com
}

\begin{abstract}
Abstrak
Penyakit diabetes melitus (DM) merupakan penyakit kronis menyebabkan gangguan metabolisme dengan meningkatnya kadar gula dalam darah karena insufisien fungsi insulin. Pada pasien penderita diabetes melitus bisa terkena penyakit lain yang di sebut komplikasi seperti penyakit jantung dan gagal ginjal, di tambah dengan masalah sekarang penderita diabetes melitus juga terancam terpapar virus corona (covid19) dan lambat laun akan dapat menyebabkan terjadinya kematian pada penderita komplikasi diabetes melitus. Informasi yang di butuhkan untuk menguatkan dan menberikan solusi sangat penting agar bisa menjalani hidup dimasa pandemi ini. Pada pasein penderita diabetes melitus diharapkan memiliki perilaku yang sehat dan rajin berolahraga di rumah demi menjaga stamina tubuh dan mengikuti pengobatan yang dilakukan selama ini.
\end{abstract}

Kata kunci : diabetes melitus, covid-19.

\begin{abstract}
Diabetes mellitus (DM) is a chronic disease that causes metabolic disorders with increased blood sugar levels due to insulin function insufficiency. Patients with diabetes mellitus can get other diseases called complications such as heart disease and kidney failure, plus the current problem that people with diabetes mellitus are also at risk of being exposed to the corona virus (covid-19) and will gradually cause death in people with diabetes complications. mellitus. The information needed to strengthen and provide solutions is very important in order to be able to live life during this pandemic. Patients with diabetes mellitus are expected to have healthy behavior and diligently exercise at home in order to maintain body stamina and follow the treatment that has been carried out so far.
\end{abstract}

Keywords: diabetes mellitus, covid-19 


\section{LATAR BELAKANG}

Pada saat ini seluruh dunia sedang mengalami masa pandemi yang mewabahnya covid-19, salah satunya di indonesia. Kondisi dimana banyaknya penyebaran masalah kesahatan yang timbul karena terpapar covid-19 ini. Gangguan kesehatan ini menyerang orang dengan atau tanpa penyakit, dengan gejala-gejala yang di timbulkan meliputi demam, batuk kering dan merasa kelelahan, adapun orang yang terpapar virus ini tidak memiliki gejala-gejala tersebut, apalagi pesien dengan gangguan metabolisme seperti diabetes melitus akan terancam terpapar covid-19 (kementrian RI, 2020). Diabetes melitus atau disingkat dengan DM merupakan penyakit kronis atau penyakit yang berlangsung jangka panjang yang ditandai dengan meningkatnya kadar gula (glukosa) dalam darah melewati batas nomal. Kasus covid-19 pada bulan juni 2021 di seluruh dunia secara global diperkiran sebanyak 180.817.269 kasus aktif, termasuk kematian sekitar 3.923.238 jiwa dengan ini terkonfirmasi sebanyak 223 negara mengalaminya (WHO, 2021). Kasus diabetes mencapai 5,2 0 /0 pada orang dewasa yang berusia 20-79 tahuh. kasus kematian diabetes melitus akan meningkat karena adanya wabah virus ini, bahkan analisis pusat pengendalian dan pecegahan penyakit terdapat 2.681 kasus di bawah umur 65 meninggal dengan covid dan hampir setengah setengah orang dari penderita diabetes (rafie, 2020).

Pasien diabetes melitus sering kali terpapar covid tampa gejala, penderi sering kali mengalami polyuria (sering buang air kecil), polydipsia (sering merasakan haus), dan polifagia (sering merasa lapar atau banyak makan). Pada pasien diabetes tipe 1, gangguan ini disebabkan sistem kekekalan tubuh yang biasanya menyerang dan menghancurkan sel penghasil insulin. Akibatnya, tubuh kekurangan atau bahkan tubuh tidak dapat memproduksi sel insulin sehingga gula yang seharusnya diubah menjadi energi oleh insulin tidak dapat berubah sehingga menyebabkan menumpuknya gula dalam darah. Sedangkan pada pasien diabetes tipe 2, tubuh bisa menghasilakan insulin secara normal, tetapi insulin tidak digunakan secara normal untuk mengubah gula menjadi energi. Kondisi ini dikenal sebagai resistensi insuli, oleh karena itu pasien dianjurkan untuk berolahraga secukupnya. Pasien pada tipe 2 ini memiliki resiko lebih tinggi terpapar covid-19. Gejala yang sering muncul setelah terpapar covid-19 adalah demam, batuk, sesak napas, merasa kelelahan, sakit kepala, dan kehilangan indera penciuman.

\section{KASUS/MASALAH}

Bahaya apa yang di dapat penderita terpapar covid-19?

\section{TINJAUAN PUSTAKA}

Namun, penderita diabetes mungkin memiliki risiko lebih tinggi mengalami komplikasi parah, seperti kesulitan bernapas atau pneumonia. Menurut penelitian Pusat Pengendalian dan Pencegahan Penyakit AS (CDC), secara khusus, bukti yang ada menunjukkan bahwa orang dengan diabetes tipe 2 memiliki risiko lebih tinggi terkena penyakit parah akibat Covid-19. Gejala Covid-19 cenderung muncul 2-14 hari setelah terpapar virus SARS-CoV-2 dan dapat mencakup: demam, batuk, sesak napas, kelelahan, sakit kepala, kehilangan bau atau rasa baru, Secara umum, infeksi lebih serius terjadi pada penderita diabetes. 
Salah satu alasannya, diabetes mempengaruhi cara kerja sistem kekebalan tubuh sehingga membuat tubuh lebih sulit melawan viruss.Selain itu, diabetes menyebabkan kadar gula darah tinggi dan virus corona baru dapat berkembang biak di lingkungan dengan kadar glukosa darah tinggi.diabetes juga membuat tubuh dalam keadaan peradangan tingkat rendah, yang membuat respons penyembuhannya terhadap infeksi menjadi lebih lambat.Kadar gula darah tinggi dikombinasikan dengan keadaan peradangan yang terus-menerus membuat penderita diabetes jauh lebih sulit untuk pulih dari Covid-19.Oleh karena itu, penderita diabetes yang mengalami gejala Covid-19 haru segera diperiksakan ke dokter.Sebuah penelitian yang dilakukan oleh CDC menunjukkan, orang dengan diabetes yang mengembangkan Covid-19 mungkin memiliki 7,3 persen risiko kematian.angka ini lebih tinggi daripada risiko terhadap penderita kanker yang mencapai 5,6 persen.penderita diabetes dapat mengurangi risiko terkena penyakit parah.komplikasi Covid-19 pada penderita diabetes,Covid-19 dapat menyebabkan komplikasi serius pada penderita diabetes.beberapa komplikasi yang mungkin dialami adalah sebagai berikut.Ketoasidosis diabetik selama periode stres atau sakit, kadar gula darah dapat meningkat. Ketoasidosis diabetik (DKA) terjadi ketika seseorang dengan diabetes tidak memiliki cukup insulin yang tersedia untuk mengatasi peningkatan ini.

\section{PEMBAHASAN}

Diabetes melitus (DM) didefinisikan sebagai suatu gangguan metabolisme yang kronis dengan multi etiologi yang ditandai dengan tingginya kadar gula dalam darah disertai dengan gangguan metabolisme karbohidrat, lipid, serta protein akibatnya insufisiensi fungsi insulin tidak normal. Diabetes terbagi menjadi diabetes melitus tipe 1 dan diabetes melitus tipe 2. Diabetes tipe 1 merupakan suatu kondisi dimana pankreas memproduksi insulin sedikit ataupun tidak sama sekali, sedangkan diabetes tipe 2 merupakan suatu kondisi kronis yang mempengaruhi proses gulah dalam darah (glukosa). Covid-19 merupakan penyakit menular pada mulanya berasal dari kota Wuhan, Tiongkok pada akhir bulan 2019 dan tersebar ke seluruh dunia. Penyebarannya seperti penyakit lain pada umumnya, melalui: percikan air liur (Droplet), sentuhan tangan ataupun wajah sang pengidap serta menyentuh hidung, mata, atau mulut setelah memegang barang atau benda yang sudah tersentuh oleh seseorang yang sudah terjangkit covid-19. Situasi yang kurang mendukung dan banyaknya berita yang beredar di masyarakat membuat kekawatiran dan kebinguan yang mendalam bagi masyarakat. Maka dari ini sosialisasi kesehatan sangat di butuhkan oleh masyarakat di masa pandemi seperti sekarang ini khususnya bagi masyarakat penderita diabetes melitus. Diabetes menjadi salah satu masalah besar diberbagai dunia salah satunya indonesia. Diabetes melitus merupakan salah satu penyakit kronis yang paling banyak dialami masyarakat. Menurut peneliti pusat pengendali dan pencegahan penyakit AS penderita diabetes melitus tipe 2 memiliki resiko lebih tinggi terkena penyakit parah akibat covid-19. Diabetes mempengahuri cara kerja sistem kekebalan tubuh sehingga tubuh sangat sulit melawan virus. Selain itu diabetes menyebabkan kadar gulah dalam darah tinggi sehingga virus corona dapat berkembang biak di lingkuangan dengan kadar glukosa dalam darah tinggi. Pasien diabetes melitus seringkali terpapar covid-19 tanpa gejala, tetapi ada juga yang mengalami gejala seperti: penderita sering kali mengalami polyuria (sering buang air kecil), polydipsia (sering merasa haus), dan polyfagia (sering mengalami lapar atau banyak makan). Sebuah penelitian menunjukkan, orang dengan pengidab diabetes dan terpapar covid-19 mungkin memiliki presentasi 7,30/0 beresiko kematian (menurut CDC). Angka ini lebih tinggi dibandingkan dengan resiko terhadap pendeita kanker yang mencapai 5,6 $0 / 0$. Namun, dengan mengontrol gula darah dapat mengurangi resiko terkena penyakit yang lebih parah dan dalam penanganan diabetes melitus salah satu yang paling penting adalah mengatur pola makan (Gregg et al., 2016). 


\section{KESIMPULAN}

Pada saat ini seluruh dunia sedang mengalami masa pandemi yang mewabahnya covid-19, salah satunya di indonesia. Kasus covid-19 pada bulan juni 2021 di seluruh dunia secara global diperkiran sebanyak 180.817.269 kasus aktif, termasuk kematian sekitar 3.923.238 jiwa dengan ini terkonfirmasi sebanyak 223 negara mengalaminya (WHO, 2021). Kasus diabetes mencapai 5,2 0/0 pada orang dewasa yang berusia 20-79 tahuh. Pasien diabetes melitus sering kali terpapar covid tampa gejala, penderi sering kali mengalami polyuria (sering buang air kecil), polydipsia (sering merasakan haus), dan polifagia (sering merasa lapar atau banyak makan). Pada pasien diabetes tipe 1 , gangguan ini disebabkan sistem kekekalan tubuh yang biasanya menyerang dan menghancurkan sel penghasil insulin.

\section{SARAN}

Semakin komplek faktor resiko diabetes melitus, sehingga perlu strategi yang memungkinkan untuk mencegah dan menurunkan angka kejadiannya melalui pengaturan dan pengontrolan konsumsi makanan yang melibatkan anggota keluarga. 


\section{DAFTAR PUSTAKA}

Sodik, M. A., \& Nzilibili, S. M. M. (2017). The Role Of Health Promotion And Family Support With Attitude Of Couples Childbearing Age In Following Family Planning Program In Health. Journal of Global Research in Public Health, 2(2), 82-89.

Dr.Rizal Fadli. 2021. Penyakit diabetesgejala, penyebab, dan cara mengobati. https://www.halodoc.com/kesehatan/diabete s

Galih pangestu jati, 2021 bahaya covid-19 pada penderita diabetes. https://health.kompas.com/read/2021/08/06/ 133100368/bahaya-covid-19-padapenderitadiabetes? newnavbar $=1 \&$ page $=2$

Kementrian Kesehatan Republik Indonesia. 2020. 13,2 persen pasien covid-19 yang meninggal memiliki penyakit hipertensi. https://www.kemkes.go.id/article/print/2010 1400002/13-2-persenpasien-covid-19-yangmeninggal-memiliki-penyakithipertensi.html

Dr.Rizal Fadli. 2021. Coronavirus-Gejala, penyebab, dan mengobati. https://ww.halodoc.com/kesehatan/coronavir us.

World Heald Orhanization. 2020. Coronavirus (COVID-19) Dashboard. https://covid19.who.int/

Kementerian Kesehatan Republik Indonesia. 2020. Penyakit Diabetes Melitus. http://p2ptm.kemkes.go.id/informasi-p2ptm/ penyakit-diabetes-melitus/page/3 